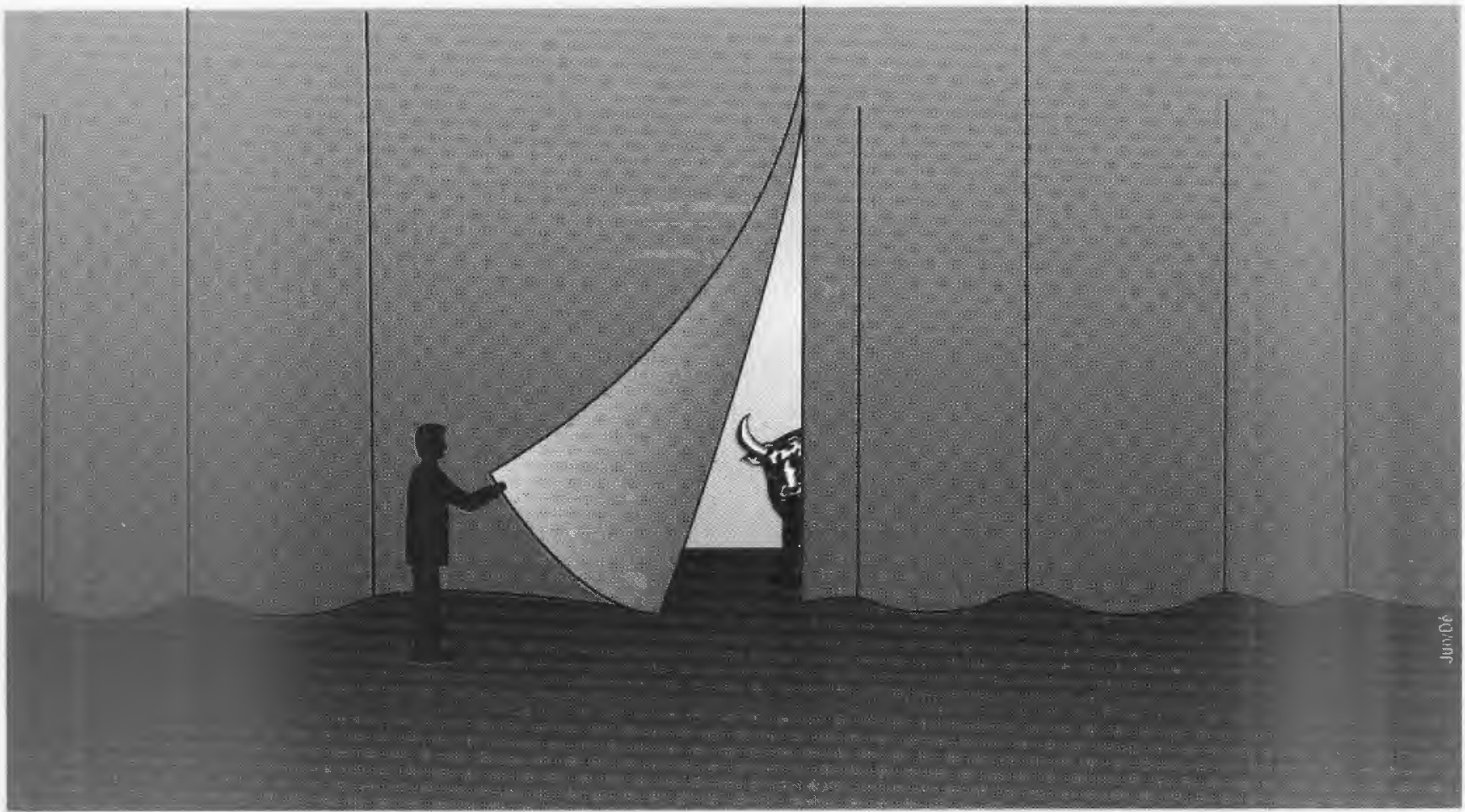

\title{
A ADMINISTRAÇÃO PÚBLICA PARA A DEMOCRACIA: ALGUNS ASPECTOS ESTRATÉGICOS - $\mathrm{II}^{*}$
}

- José Constantino Nalda García

Presidente do INAP - Instituto Nacional de

Administración Pública, Espanha.

Tradução de José Roberto Felicíssimo, Sociológo, Doutor em Ciências Sociais, Professor Assistente-Mestre da FEA-PUC/SP, Consultor.

* RESUMO: Este artigo é o segundo de uma série de três sobre as bases que sustentam a modernização administrativa no setor público espanhol. Está estruturado de forma modular, sem remeter o leitor necessariamente ao primeiro artigo da série. Em particular, nesta segunda parte, o autor focaliza sua atenção na resposta às questões: para que a Administração Pública? Como torná-la realidade? Utiliza o referencial teórico apresentado na Parte I e introduz o conceito de "espaço de qualidade" para superar as dimensões custo-beneficio. Delimita este espaço com três eixos: limitação de recursos, novas tecnologias e informação, com os quais analisa o papel central do capital humano na nova organização prestacional e de garantias, com base no caso espanhol, apontando dificuldades $e$ possíveis ações futuras.
* PALAVRAS-CHAVE: Administração Pública, democracia, espaço de qualidade, capital humano, organização.

* ABSTRACT: This article is the second of a three serie about the base that support the administrative modernization in the Spanish public sector. It is structured in a modular way, without send the reader to the first article. Especially, in the second part, the autor focus his attention on some questions as: what for public administration? How to make it reality? He uses the theoretical frame of reference presented in Part I and introduces the "space of quality" concept to surpass the dimensions of cost-benefit analysis. Such space is framed by three axes: limited resources, new technologies and information. Based on Spanish case the autor analises the central role of human capital in the new organization which offers services and guarantees. He points out difficulties and possible future actions.

* KEY WORDS: Public administration, democracy, space of quality, human capital, organization.

* Artigo publicado originalmente sob o título La Administración Pública para la Democracia - alguns aspectos estratégicos, pelo Centro Latinoamericano de Administración para el Desarrollo (CLAD), Caracas, Venezuela. 


\section{O ESPAÇO DA QUALIDADE}

Consideraremos, sob esta epígrafe, a resposta a uma pergunta que seria imediata ao que acabamos de analisar: para que a Administração? O nosso interesse, e daí o título, é superar esquemas muito lineares - de certo modo também antiquados - de abordar estas questões.

No desenvolvimento realizado até o momento, aprecia-se com facilidade, que a Administração tem tido como objeto manter as estruturas dominantes e a perpetuidade do modelo de rigidez e estabilidade que descrevemos. Era, portanto, uma Administração de normas e potentados (domínio) (potestades) para, numa similitude esportiva, manter as regras do jogo, os limites do campo e os jogadores paralisados em posições predeterminadas, o que, às vezes, exigia o outorgamento - gracioso? - de certos benefícios ou serviços sociais e, além do mais, de um sistema que evitasse as perturbações. ${ }^{1}$

Este não pode ser o espaço em que deve se mover uma Administração numa sociedade democrática, plural, complexa e dinâmica como a descrevemos. $O$ estabelecimento de condições gerais de acesso aos bens e serviços sociais, para um exerć́cio real das liberdades e a igualdade; a participação e o controle que deverão ser estabelecidos sobre as políticas públicas que definem a produção e distribuição desses bens, e sobre aqueles que tenham a responsabilidade na decisão e execução; as exigências que venham a derivar de uma maior qualidade; e menores custos (diretos ou indiretos) a serem suportados pelos cidadãos, são eixos que definem um âmbito completamente distinto para as ações administrativas.

Neste estágio da questão é conveniente fazer uma pequena digressão para enriquecer a perspectiva que estamos explorando. Iniciamos com algumas perguntas que, de imediato, responderemos. Desde este novo marco, não observamos semelhanças com objetivos, métodos e proposições que pareciam reservados, anteriormente, ao domínio privado? Não são coincidentes as exigências das demandas com as que se realizam às empresas que oferecem bens e serviços? Não está sendo solicitada, ao mesmo tempo, maior intervenção reguladora e impulsionadora, em setores da economia anteriormente considerados como paradigmas da ação priva$\mathrm{da}$ ? E, finalmente: poderia ser esperada outra evolução, considerando-se que a manutenção de uma sociedade desenvolvida, moderna e eqüitativa requer uma gestão eficaz para boa parte da riqueza nacional? ${ }^{2}$ As respostas surgem sem dificuldade. Um país que pretenda manter um sistema democrático e descentralizado de poder, que tenha a eqüidade e a justiça como princípios orientadores e que gere um grau razoável de bem-estar, necessita de uma Administração que introduza critérios de eficiência, eficácia e qualidade em sua gestão.

Não é estranho, portanto, o título dado a esta seção, já que trata-se de ver a Administração funcionando, transformando recursos (inputs) nos serviços que satisfazem as aspirações (outputs). Tal esquema deve ser considerado a partir de dois ângulos diferentes e complementares: o âmbito psicológico e subjetivo daquilo que se deseja e a medida do esforço que se está disposto a suportar, ou a perspectiva mais racional dos parâmetros econômicos de custo-benefício.

$\mathrm{Na}$ figura 1, representamos a tendência de um processo no plano do custo-benefício. É evidente que cumpre-se o ideal sempre para a linha de rendimento máximo que se corresponderia com aquelas de menor custo e máximo benefício. Pelo contrário, uma situação indesejável corresponderia com aquela de maior custo e menor benefício. Em todo caso, o que pode ser entendido como socialmente aceitável move-se em uma fronteira de flutuação definida em custos e benefícios, de modo que na realidade o processo de prestação de um serviço deve evoluir desde os pontos que representam maior custo e mínimos benefícios aos associados com menores custos e máximos benefícios com a introdução de mecanismos de eficácia e eficiência.

Sem dúvida que o processo não responde a uma trajetória simples de ida e regresso, senão que apresenta aspectos de inércia e memória (recuerdo) que modificam as tendências e lhes dão maior complexidade e, ao mesmo tempo, um grau de dinamismo que pode facilitar a manutenção de entornos de estabilidade. A figura 2 representa o que seria este
1. Uma segunda leitura - e sugestões de bons amigos! obrigam-me a suavizar as afirmações deste parágrafo, principalmente, com o relacionado a seguir. Em primeiro lugar, evitar qualquer sensação, ou tensão, entre etapas: uma, perversa e, a outra, cheia de possibilidades. Nada é assim e, sobre isto, mais uma vez, pode-se encontrar uma prova de que o processo passa por sucessivos estágios intermediários de nãoequilíbrio, nos quais se auto-organizam os distintos componentes. Neste dinamismo, a Administração também jogou seu papel: às vezes, como elemento de rigidez $e$, outras - muitas, se considerarmos os últimos tempos da ditadura espanhola produzindo as condições de profissionalização que favoreciam a dinâmica renovadora.

2. Na Espanha, aproximadamente $45 \%$ do valor bruto agregado é gerido pelo conjunto das Administrações públicas; e, desse total, $60 \%$ é destinado a beneficiários e agentes privados. 


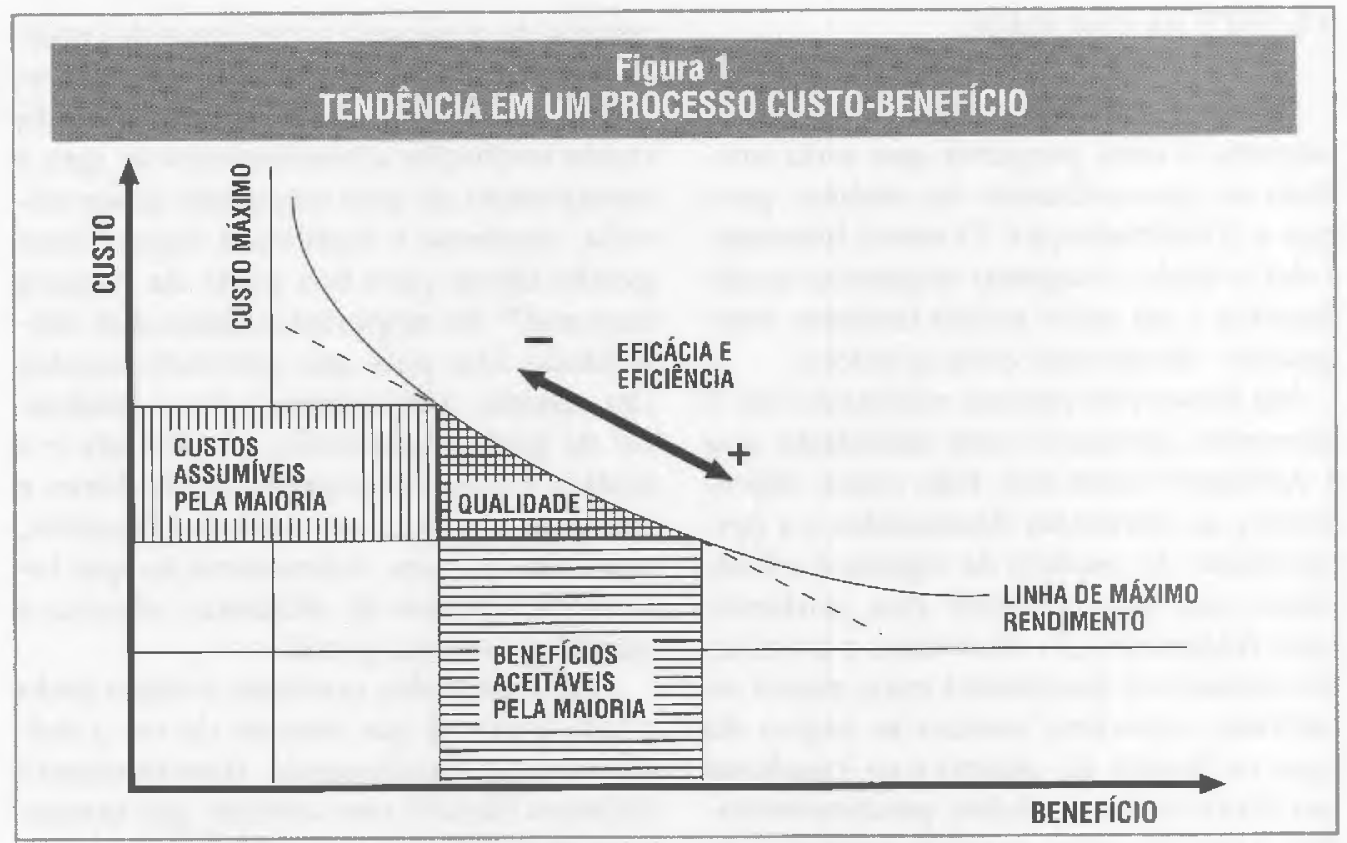

processo dinâmico de qualidade. Observando-se a figura, obtém-se as razões que estamos explicando. Em primeiro lugar, existe uma tendência natural nos indivíduos e nos agrupamentos - se permitem utilizar o termo cliente ou equivalente - a maximizar benefícios e a reduzir custos. Como indicamos anteriormente, existem alguns valores mínimos e máximos que, por umas ou outras razões, não podem ser ultrapassados, muito embora que, durante o dinamismo, sempre seja produzido um certo grau de deslocamento, em função do sentido da

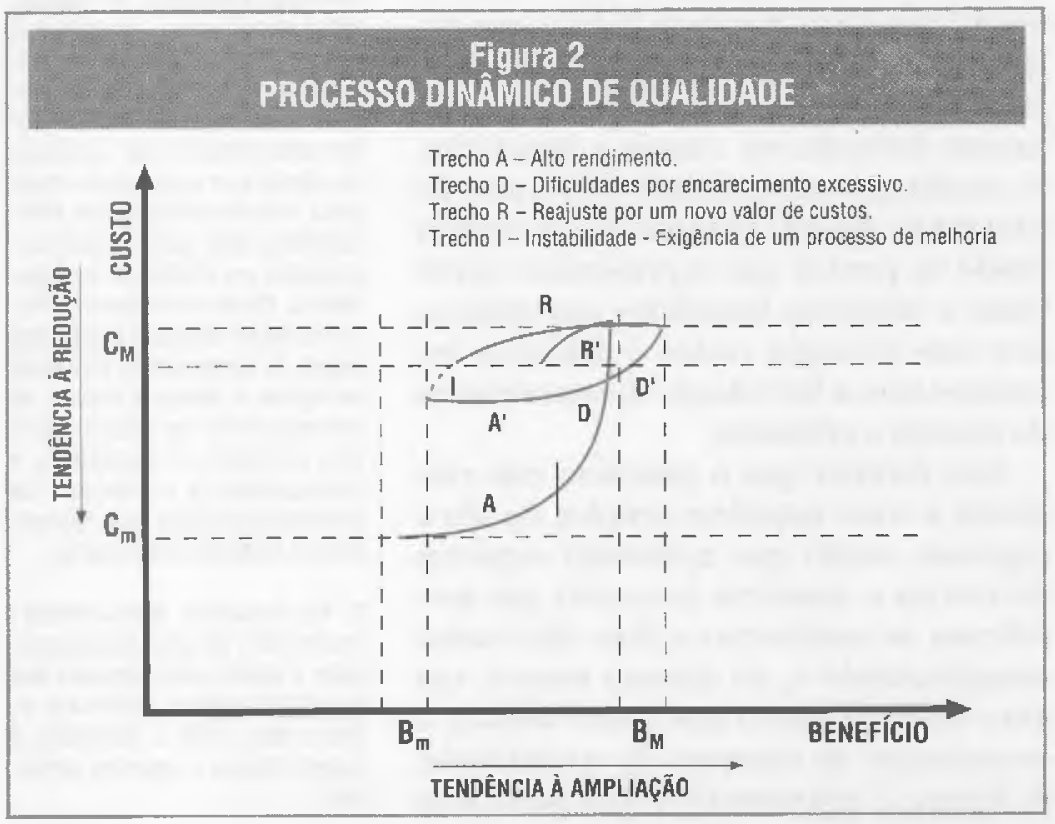

tendência. Isto corresponde com os valores $\mathrm{Bm}$ e $\mathrm{BM}$ para os benefícios mínimos e máximos e $\mathrm{Cm}$ e $\mathrm{CM}$ para os custos equivalentes. Abaixo de um determinado nível de benefício $\mathrm{Bm}$ mesmo que fora a um custo menor de $\mathrm{Cm}$, o cliente recusa o serviço e, também, o produtor não se coloca essa situação como desejável na empresa. A partir daí, está demonstrado que podem ser produzidos incrementos notáveis de benefícios, com suaves aumentos de custos, principalmente se se procura melhorar a eficácia e a eficiência concomitante com uma adequada atividade promocional. A partir de um determinado ponto a evolução muda mais bruscamente, de modo que para suaves melhoras no benefício aparecem custos que se elevam, aproximando-se, rapidamente, do valor máximo que em tal configuração está-se disposto a suportar. Isso obriga os responsáveis a rever o sistema produtivo, a linha de oferta, o incremento do rendimento, automatização, realocação de recursos humanos etc., isto é, voltar a situações de menor custo.

O que acontece, então? Simplesmente, para manter o interesse pela qualidade por parte dos clientes, vão se realizando ajustes suaves que, às vezes, não são tão reduzidos, considerados sob a ótica dos benefícios. Assim, a trajetória seguirá uma curva afastada (alejada) e sobre a anterior até que os defeitos na qualidade da nova configuração não possam ser assu- 
míveis. Neste momento teria início uma nova trajetória, deslocada da anterior, em origem e em ponto de possível retorno, gerando-se um novo itinerário de qualidade. O processo terá estabilidade e existirá ưma relação frutífera e positiva entre prestadores e usuários do serviço se as trajetórias estiverem incluídas dentro da área delimitada pelos valores múnimos e máximos que definam a adequada relação de custos e benefícios.

É possível completar esta visão se marcarmos o processo de qualidade em um espaço pluridimensional tomando-se em conta três eixos direcionais, que já consideramos em outras seções, e que superam, se bem que sob condições, as dimensões custo-benefício. Em primeiro lugar, é evidente que os processos de produção e prestação de serviços ocorrerão com "limitação de recursos". Não é possível pensar em crescimentos ilimitados de demanda sem ter presente que vêm condicionados pela finitude e conservacionismo dos recursos.

Um segundo eixo seria aquele associado com as novas tecnologias. E uma orientação que vem contribuir para superar os impedimentos anteriores mas, que, por sua vez, gera necessidades de adaptabilidade, flexibilidade e acomodação nus processus produtivos e na capacitação dos recursos humanos. ${ }^{3}$

A terceira direção, com a qual vamos construir nosso espaço de qualidade de serviços, está associada à informação como elemento de intercomuniçação e de realimentação entre a oferta e as demandas.

Isso está na figura 3 naquilo que chamamos de o "tetraedro da qualidade". Cada plano configurante é a zona de encontro entre o exterior - clientes e usuários - e o interior - Administração, no caso - ressaltando, fundamentalmente, o papel especial que jogarāo os recursos humanos e algumas qualidades favoráveis para resolver as áreas de contacto.

O espaço da qualidade, como o chamamos, é essencial para responder com validade a pergunta colocada no início desta seção: para que a Administração? Como considerá-la na realidade?

Chegamos, pois, ao papel central que os recursos humanos devem desempenhar nesta organização prestacional e de garantias que é a Administração. Percor-

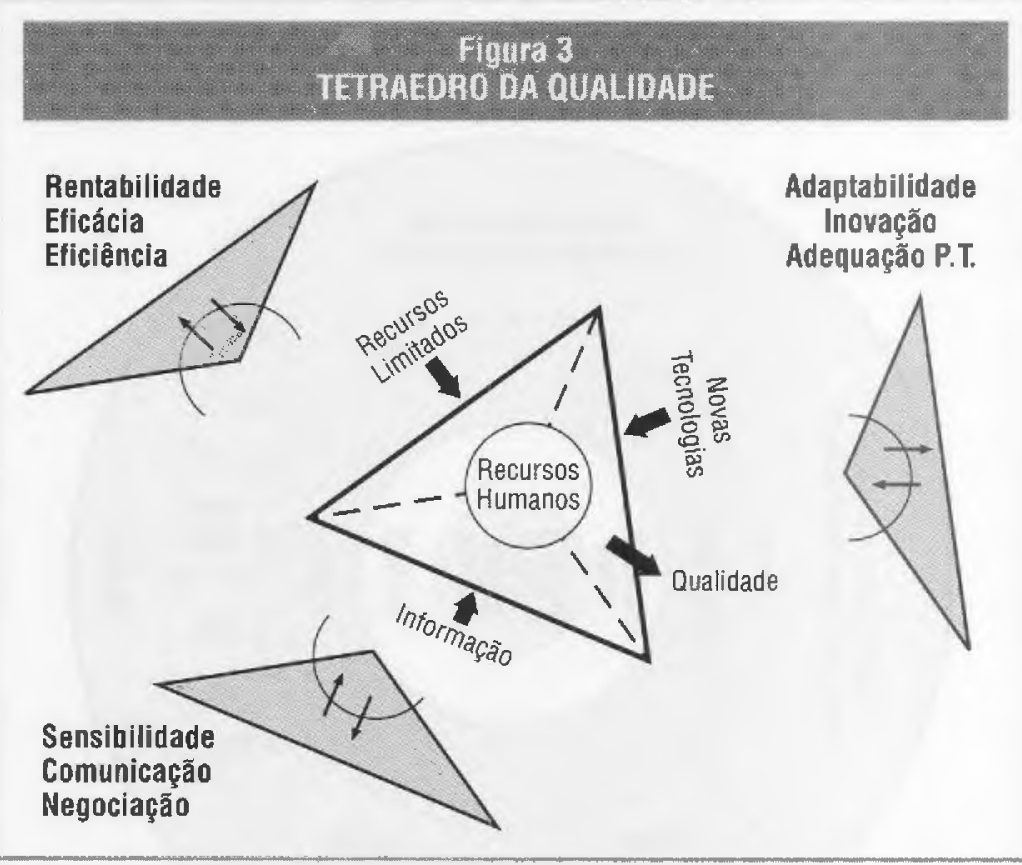

remos, para isso, desde a idéia de Administração em permanente atualização para realizar suas missões em uma sociedade em mudança, não univocamente determinista que, como conseqüência das contribuições tecnológicas, move-se em um espaço de probabilidade e incerteza, passando pelos processos dinâmicos que permitem manter graus de estabilidade na qualidade dos atendimentos exigidos pelos cidadãos para exercer, realmente, seus direitos e liberdades. As seções seguintes são dedicadas, portanto, à analise do papel dos recursos humanos.

\section{OS RECURSOS HUMANOS NA ORGANIZAÇÃO ADMINISTRATIVA}

Se o tetraedro é o espaço de definiçăo da Administração como organização funcionando - com o intercâmbio, através das superfícies, dos recursos e insumos, os bens e serviços, a inovação e a informação - os recursos humanos aparecem como o elemento dinâmico do sistema. Tentaremos construir uma figura compreensiva dos âmbitos distintos com os quais se relaciona, como se configura e qual o papel que joga a denominada cultura administrativa (ver figura 4).

Em síntese, são produzidas duas grandes áreas de necessidades e interesses que se comunicam e dão origem à cultura administrativa. Desde o exterior, e coe-
3. A respeito de todas essas questões convém consultar os trabalhos de pensadores como Peter Drucker, R. Muller ou K. Bleicher. Eles entendem que, no futuro, o elemento humana será o fator decisivo para permitir a descoberta das oportunidades e evitar os riscos 


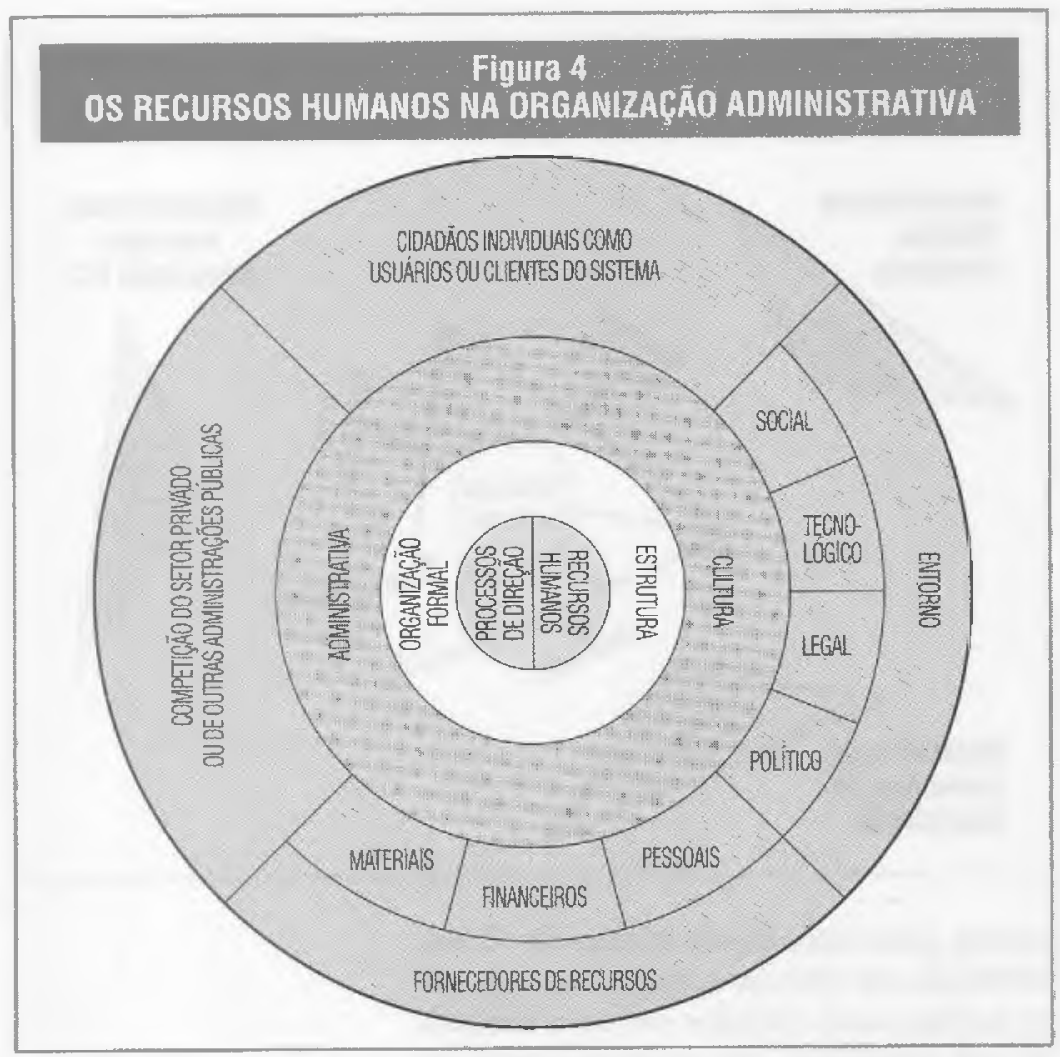

4. Algum leitor critico, dos rascunhos iniciais, apresentou-me algumas questōes que, entendo, não sāo apenas pertinentes, como requerem maior atenção. Em sintese, a pergunta poderia ser: no modelo em que estão superpostos os planos de cidadāo e cliente, como é considerada a dimensão política do cidadăo, enquanto participante, pelo voto, da definição dos projetos políticos?

Poderia pensar-se numa visão tecnocrata que rechaça a vontade politica, expressa através da concordancia ou desacordo das ofertas programáticas dos partidos politicos, através do recurso da inducão ou interpretação das preferências dos clientes, pelos encarregados do marketing público. Esta situação deve ser descartada. Mas, para isso, é peremptório que os líderes e responsáveis pelos partidos políticos entendam, também, qual possa ser o seu lugar em uma sociedade aberta e pluralista, com múltiplos caminhos e mecanismos de interação e afastada dos principios deterministas que sustentaram sua formação no século $X I X$. Para que cumpram com os objetivos de intermediação social que Ihes correspondem, e sejam capazes de formular, propor e dirigir projetos políticos que agreguem am- rente com o modelo de sociedade, estão os cidadãos como usuários ou clientes do sistema e as entidades coletivas - grupos formais ou informais - através das quais podem se constituir. Estará, aí, o entorno sócio-político, produto do próprio modelo de convivência, que será concretizado em um marco legal sobre o qual atuarão os avanços das tecnologias, em particular a informação. Estes dois grandes coletivos atuam sobre o nível de garantias e demandas. Os dois setores seguintes entram, ou podem entrar, em competição com a atividade da organização, facilitando ou dificultando o seu sucesso: os que subministram recursos (entre os quais está a potencial fonte para o recrutamento de pessoal próprio) e o setor de empresas privadas (que produzem serviços e atuarão sobre o mesmo âmbito que o setor público). ${ }^{4}$

É preciso insistir um pouco mais sobre esta parte da zona externa de influências. Já explicitamos as proximidades cada vez maiores existentes entre os modelos organizacionais público e privado, forçada pela necessidade de atender demandas, desde a eficácia à qualidade. É útil incluir a reflexão a respeito da exigência de competição com produtos análogos sobre o mesmo espectro de usuários e clientes. É cada vez mais tênue a distinção entre os clássicos sistemas produtivos de bens materiais e o atendimento dos bens imateriais ou serviços. Isto pode ser observado em qual é a distribuição da atividade nos três setores: o primário, da agricultura e a extração; o secundário, da transformação industrial; e o terciário, da distribuição, o sistema financeiro e os mecanismos assistenciais, educativos ou sócioculturais. Todos já conhecem a relação entre sociedade avançada e domínio do setor de serviços, no qual a iniciativa privada já ocupa um espaço notável, além de poder participar e receber encomendas sobre outros temas deste setor. Sendo assim, a Administração, ao conviver com esta situação, deve dispor de métodos e meios que the outorguem a capacidade suficiente para este desafio. A Administração, que não limita o seu papel à beneficência e à seguridade de finais do século passado, deve constituir-se como uma empresa com o objetivo de produção e distribuição de serviços em um sistema de concorrência, dentro de um marco jurídico de garantias e com a obrigação de contribuir para o ajuste da legalidade ao modelo de sociedade. Pode-se esquematizar com facilidade, o interior descrito na figura 4, porém não é tão simples a sua ordenação e explicação. Isto, porque estamos falando de recursos humanos e de uma organização que se constrói desde e com os próprios seres que a constituem. Uma primeira questão de esclarecimento seria a necessária separação entre o que é a Administração como sistema organizacional complexo - destinado a atender as necessidades sociais dos cidadãos em justiça e eqüidade - e o âmbito da formulaçăo e decisão das políticas que a Administraçăo deverá aplicar e executar, no qual deve-se produzir a interação, o conflito e o acordo até que se defina o modelo que atende ao interesse da maioria. Às vezes, não é tão nítida a separação e isso pode ser a causa de disfunções graves. Deve estar suficientemente claro que o espaço da definição de modelos e políticas faz parte do setor externo à Administração (ver nota 4 )

Considerados os matizes anteriores devemos, agora, ressaltar a necessidade da Administração constituir-se com a ob- 
servância de critérios organizacionais cuja origem está vinculada às seguintes perguntas: quais objetivos e finalidades temos que satisfazer? A resposta a isso condicionará a estrutura formal. Uma administração exclusivamente de potentados requer, apenas, uma linha hierárquica de comando, sem cadeia de responsabilidade, nem processos de descentralização, coordenação ou cooperação. Os critérios de qualidade, eficácia e eficiência não lhes serão aplicáveis, pois sua tarefa se justifica no próprio "império" da lei. Outra coisa ocorrerá se exigimos que a Administração produza os bens sociais necessários para o atendimento, com qualidade, das demandas. É neste momento que poderá ser apreciada a obsolescência do modelo hierárquico e centralizado; $\mathrm{e}$ será necessária uma estrutura distribuí$\mathrm{da}$, de responsabilidade dos agentes, bem informada e, acima de tudo, capaz de responder com critérios análogos aos que são produzidos nas entidades privadas complexas.

Falta, sem dúvida, uma referência a um elemento estratégico fundamental neste tipo de organização: os dirigentes e responsáveis intermediários. Os primeiros, como planejadores, impulsionadores e elementos de inter-relação com a esfera de decisão. Os segundos níveis, mais próximos à execução e ao atendimento dos clientes, são decisivos para que funcione a realimentação do sistema, ajustando a oferta de serviços à demanda e aos critérios de satisfação.

Todo este conjunto configura a "cultura administrativa", quando se observa, desde o exterior, com um caráter de globalidade e, às vezes, desde a parcialidade. Diríamos que é somente - mas quanto! - uma visão mediada (promediada)suavizada, portanto, em defeitos e virtudes - da Administração, de seus recursos humanos, funcionando. E, em conseqüência, a observamos com lentes diferentes, segundo a sensibilidade, a atenção ou a insatisfação do observador. Reconhecendo isso teremos, portanto, que realizar maiores esforços para que essa faixa da imagem seja o reflexo da Administração modernizada que responda adequadamente aos desejos daqueles que fornecem os recursos e esperam alguns benefícios de seu correto funcionamento.
Não é menos certo, também, que o interior veja o exterior através da "cultura administrativa". Os empregados públicos, os funcionários, contemplam os demais cidadãos através dela. Daqui se deduz uma condição qual seja que a película não seja convertida em bolha protetora, separadora e deformadora da realidade. Antes, pelo contrário, deveria ter as características ópticas que facilitem a concentração no interior de quantas informações cheguem do exterior para poder emitir a necessária e adequada resposta.

Novamente nos encontramos com um símile dinâmico de membrana comunicadora através da qual fluem sinais que indiquem as deficiências e os produtos que, gerados rapidamente, atendam a sua proteção e cuidado. A Administração será, assim, um sistema aberto. Como é, também, a pergunta que deriva de imediato: como gerir, neste marco conceitual, a crucial questão das políticas de recursos humanos no setor público? As próximas seções são dedicadas a encontrar algumas respostas.

\section{POLÍTICAS DE RECURSOS HUMANOS EM ADMINISTRAÇÃO PÚBLICA: O CASO ESPANHOL}

É o momento de concretizar com um caso prático e nenhum é mais apropriado do que a nossa própria experiência. Para facilitar o acompanhamento, estabelecemos um esquema temporal em que se considera o período 1984-1986 como de mudança de tendência. Antes disso existia somente uma administração de pessoal. Durante esses dois anos são percebidas as incongruências do modelo vigente, em relação com as expectativas gerais da sociedade e das demandas geradas sobre a Administração; e é a partir de 1986 que começa a considerar-se a Administração como empresa prestadora de serviços que, por sua vez, necessita de uma atualização permanente de seus métodos, procedimentos e ofertas para entregar aos cidadãos-clientes os bens requeridos. É, então, que se nota a ausência de uma autêntica política de recursos humanos e se inicia o caminho para superar tais carências. Estamos, pois, imersos no processo de moderniza- plos interesses cidadãos e coletivos, devem dispor dos mecanismos de análise, comunicação e avaliação que, conforme detectamos, existem em outras corporações industriais e de serviços, e que propusemos para a Administração. Somente assim serão capazes de oferecer alternativas que dentro de cada projeto definidor no qual estejam contemplados os valores fundamentais de liberdade, justiça, eqüidade e solidariedade - congreguem os apoios necessários. Isto, como conseqüência de uma confluência preferencial entre os interesses individuais e coletivos - mas, egoístas - com aqueles propostos pelo partido político, com 0 louvável propósito, da mais ampla extensão que pode tender, em certas situações, à universalidade.

0 novo panorama consistiria em parlamentos eleitos, representando as vontades políticas dos cidadãos, configuradas pelo conhecimento das alternativas aos seus problemas mutáveis, que thes são oferecidas por Partidos Políticos que ajustam suas propostas a um marco definido de valores. Sua tarefa, então, seria a de planejamento superior das políticas públicas, a partir da realidade social plural e o controle sobre o exercício destas políticas, com a dupla missão de acompanhar a realização do que foi projetado e de comunicar-se com o cidadão, para perceber a satisfação, ou não, de suas aspirações, tendo em vista o prosseguimento ou a correção das políticas planejadas.

Neste esquema, como instrumento de execução, a Administração na elaboração dos planos e projetos; aconselharia sobre as normas que, no seu entender, são mais adequadas para alcançar os fins propostos; prestaria, com diligência e eficácia, os atendimentos esperados pelos cidadãos-clientes, deduzidas da concretização em políticas públicas da planificação política; comunicaria os sucessos e fracassos e carências observados na aplicação das diversas políticas; e estaria submetida ao controle, associado com a avaliação de suas atividades, tanto em relaçāo às suas competências executivas, como em relação à materializaçāo, através de sua ação, dos planos e projetos políticos aprovados pelo Parlamento, como expressão dos interesses e da vontade dos cidadãos. 
ção que acompanhará as mudanças organizativas e estruturais, com a adequação dos recursos pessoais e materiais para que o resultado seja uma cultura administrativa que forneça, com eficácia, eficiência e qualidade, os atendimentos públicos.

$\mathrm{Na}$ figura 5, estão sintetizados os elementos mais característicos desses períodos, mencionando como objetivos a cumprir os que se indicam à guisa de compromisso para o período pós 1986, no qual estamos transitando.

Uma advertência preliminar é que o processo espanhol que estamos comentando não está excessivamente afastado dos processos análogos produzidos nos países de nosso entorno. É sabido que os elementos de crise, associados à limitação de recursos, à implantação de novas tecnologias e às exigências de maior qualidade e competitividade são os que obrigam os responsáveis políticos a tomarem decisões que conduzam a uma Administração mais eficiente e eficaz - e menos burocratizada - que adquire legitimidade à medida que saiba atender melhor os cidadãos. ${ }^{5}$ Daí que, no transcurso dos últimos anos, tenha se produzido uma eclosão de ações tendentes à modernização (renouveau, na França) das Administraçōes Públicas.
5. É este $O$ caso de algumas das reformas empreendidas recentemente, na França, Japāo e Suécia. Em nossa opiniāo, afastam-se dessa perspectiva, por sua origem ou por seus fins, as citadas por outros comentaristas, referentes à Grä-Bretanha ou aos Estados Unidos; se bem que é verdade que nestes países, produziu-se uma mudança notável na orientação original após as últimas mudanças politicas.

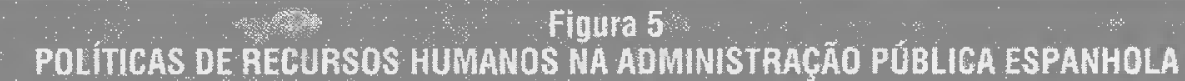

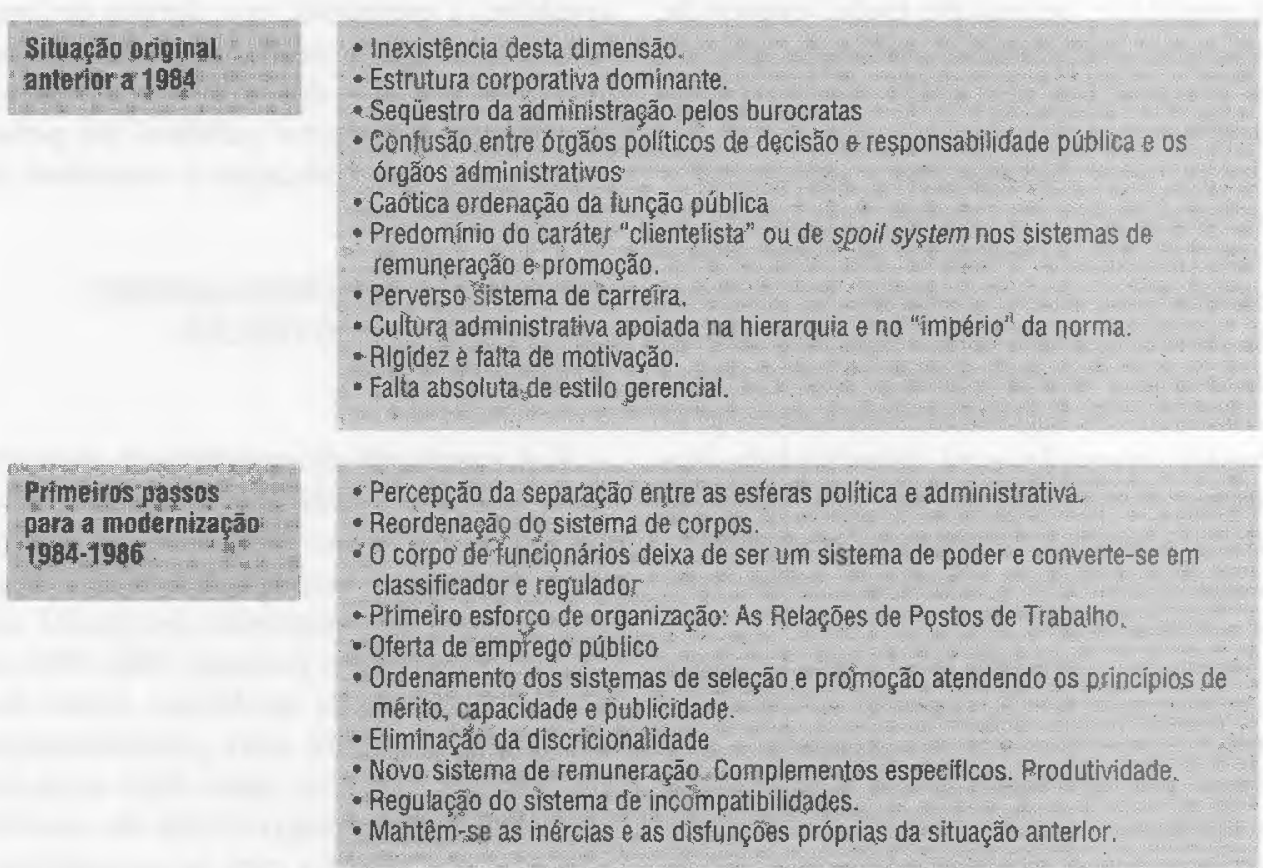

A modernização como processo permanopte de adequaçăo (posterior a 1986)

- Identificação-de anomalias que dificultam as previsões de reforma.

- Necessidade de uma política de RH compativel com as previsōes da organizacăo.

- Superaçẫo da simples administração de pessoal

- Identificação de programas, projetos e objetivos da ofganização previamente a

definiçăo e ordenamento dós postos de trabalho.

- A administração como sistema de organizaçōes.

- Potenclalização das capacidades gerenciais.

- Atuaçãa com critérios de eficácia e eqficiência.

- Políticas de RH incentivadoras, atraentes e competitivas.

- Estímulo à iniciativa, à inovação, à autonomia e à responsabilidade

- Permanent capacitaçã̃o e formacão. Criaçăo de uma nova cultura

administrativa.

- Adequaçāo dos sistemas de ingresso aos novos perfis gerenciais e de gestão. 
Deve-se levar em conta que esses processos vêm estimulados pela necessária convergência imposta pela Comunidade Européia. A decisão de avançar nesta união implica no adequado tratamento nas administrações dos países membros, de modo que em todas elas se atue sob as mesmas pautas e critérios, sobretudo priorizando a atenção para que sejam alcançados graus homologáveis na qualidade de vida.

Mas, além disso, o processo de integração é a expressão mais evidente dessa sociedade aberta e em intercâmbio permanente. Fonte de energia que, para manter o dinamismo, requer, ao mesmo tempo que uma cultura administrativa assentada na flexibilidade, a adequação, a responsabilidade, a coordenação e a informação, em correlação ao modelo de organização que descrevemos nas seções anteriores.

Uma preocupação adicional poderia surgir se a Administração empreendesse a renovação com o pé forçado com respeito a ações análogas empreendidas pelas empresas e corporações privadas. Mas não é este o caso, antes pelo contrário, já que o que se está programando nessas matérias - desde a informação e o atendimento mais personalizado aos usuários dos serviços, passando pela implantação de sistemas de gestão baseados em critérios de rendimento e eficácia, até o impulso à gerência e direção públicas são totalmente congruentes com as iniciativas privadas. Poderíamos afirmar que existe sintonia entre as condições de modernização do conjunto da sociedade e os parâmetros que definem tais condições para a Administração.

Quando nos referimos à situação original anterior a 1984 queremos explicar que trata-se do modelo que se aplicava desde os finais dos anos 50, que é o que chega até o período mais recente. É preciso reconhecer que nas circunstâncias políticas daquele momento é meritório o esforço de profissionalização e racionalização das estruturas administrativas produzido ao lado da implantação de um sistema legitimador baseado nas garantias da norma e procedimento. Agora vejamos, sustentar a reforma administrativa no enredado (en el entramado) de corpos de funcionários, se era coerente com os postulados corporativistas do regime, introdu- zia, ao mesmo tempo, um sistema de controle que conduziria ao seqüestro burocrático da Administração, mencionado anteriormente. ${ }^{6}$ No fundo, o que acontece - e isso que comentamos o confirma é que: ou bem a sociedade, a Administração, obedece a sistemas abertos de gestão, ou o sistema é fechado, e gera a transpiração protetora mediante mecanismos reservados aos iniciados, expulsando aos restantes - inclusão feita dos próprios demandantes que seriam a justificação de sua existência.

Outros efeitos derivados desses postulados são:

a. a múltipla e caótica ordenação em sistemas de corpos da função pública concebidos, também, como redutos de poder e controle;

b. associada a isso, uma perversão nos métodos de seleção, acesso e promoção;

c. a ausência de mecanismos motivadores;

d. a falta absoluta de sentido gerencial;

e. como invólucro e imagem do conjunto, a cultura administrativa hierárquica e labiríntica, distanciada dos interesses dos cidadãos e, na mesma medida, opressora dos mesmos.

As peculiaridades do processo de transição, no caso espanhol, permitiram uma convivência - não isenta de transformação, desde o modelo corporativo próprio de "antigo regime" até o que poderia ser base profissionalizada de uma Administração para uma sociedade plural e democrática. Assim, chega-se a 1984 sem praticamente nenhuma ação que pudesse significar uma mudança de orientação. É no período 1984-1986, como indicado na figura 5, quando se percebe, em profundidade, a separação existente entre o modelo que sustenta a sociedade e o que estabeleceu as condições básicas sobre as quais se apóia a Administração. Isto dá origem às primeiras medidas regulamentadoras e legislativas com as quais se pretendia remediar a caótica situação descrita e, acima de tudo, aproximar a Administração a uma sociedade que requeria, a cada dia, mais e melhores atenções.

Convém que sejam ressaltados alguns aspectos que significaram uma mudança
6. Alguns acadêmicos viram e denunciaram os perigos de tal sistema, contribuindo com idéias que, posteriormente, foram acolhidas. 
na tendência e abriram caminho a modificações posteriores:

1. se atua sobre o sistema de corpos eliminando condicionantes na seleção, promoção, emprego e designação específica de tarefas, suportes da estrutura de poder burocrático, com a pretensão de convertê-la em mecanismo classificador e regulador dos funcionários públicos;

2. tem início um esforço de organização, de modo que os distintos Departamentos ou Organismos da Administração disponham de algumas Relações de Postos de Trabalho. Nelas, pela primeira vez na história da Administração, se recolhem sua descrição (dos postos de trabalho), incluindo desde os perfis requeridos naqueles que podem desempenhar o posto, até a carga de trabalho e tarefas encomendadas $e$, em conseqüência, os vencimentos retributivos associados. É em função destas relações e das necessidades que venham a ser produzidas anualmente que se realiza a convocação de Oferta Pública de Emprego;

3. vinculado ao anterior, produz-se uma nova orientação nos sistemas de seleção e carreira, eliminando graus de discricionariedade e atendendo aos princípios de mérito, capacidade e publicidade;

4. é estabelecido um novo sistema retributivo no qual a avaliação de desempenho e dedicação do funcionário pode ter sua satisfação mediante a aplicação dos complementos de produtividade que completam o sistema retributivo associado às qualificações e títulos pessoais e à dificuldade e especificidade de tarefas constatada nos postos de trabalho. Associado com tal processo é regulado o regime de incompatibilidade entre postos e funções a serem desempenhados simultaneamente pelos funcionários.

Desta enumeração poderíamos obter uma impressão excessivamente favorável do período que se inicia com a promulgação da Lei 30/1984 e que se prolonga, com muitas interrupções, até a sentença do Tribunal Constitucional e adequação à mesma que é realizada pela Lei 23/1988.
Sendo rigorosos, diríamos que as resistências foram muito fortes para que pudessem ser vencidas por estes, muito embora estivessem amparados pela lei. Hoje em dia as Relações de Postos de Trabalho não cumprem, nem refletem, as previsões enquanto instrumentos de planejamento fundamentais da organização. Também não foi superada a dificuldade essencial, gerada pela própria lei, de uma Administração que repousa na filosofia organizacional de distribuição de tarefas e de postos de trabalho, com a manutenção de partes do modelo de corpos, o que dá origem a graves disfunções. E, por nos limitarmos a três aspectos-chave no equilíbrio entre administração de normas e potentados ou administração de bens e serviços, impediu-se - pela inércia e por sua utilização demagógica - que o sistema retributivo cumprisse com as orientações e desejos do legislador, para que, por seu intermédio, fosse possível estabelecer um adequado sistema de controle e avaliação de desempenho.

Estamos, agora, em condições para explicar a etapa seguinte - em cujo desenvolvimento nos encontramos, e, também, para entender um aforisma romano que vem bem a calhar neste momento: "Quid lege sine moribus". Para que as leis sem costumes? Não se muda a sociedade nem, no caso concreto que estamos analisando, a Administração, sem que antes sejam produzidas transformações nos hábitos, nos costumes, que minimizem as inércias e facilitem o estabelecimento, aplicação e obediência das leis.

Com esta reflexão que se afasta no tempo, buscando a experiência daqueles ordenadores da vida pública, que foram os romanos, começamos a viagem pelos anos mais recentes. Prosseguindo com a figura do viajante, a sociedade demanda da Administração uma condução segura, sem quebras violentas, por caminho bem definido e com estações e apeadeiros onde cada um possa se abastecer dos bens e atenções requeridos por uma melhor qualidade de vida. $E$ isto, sem que o preço do desfrute seja insuportável, tornam inviáveis novos itinerários ou pontos de abastecimento ou, ainda, a questão fundamental, que o veículo, além de confortável, tenha manutenção permanente. Isto significa que a Administração 
deverá ser cada vez mais organização, complexa e em processo dinâmico de adaptação, que rechaça fórmulas estereotipadas e rígidas para que possa cumprir, com qualidade, suas funções de produtora e provedora de serviços. Como conseqüência, deve-se introduzir uma política para os recursos humanos, que esteja compatibilizada às previsões da organização e superadora das disfunções resumidas anteriormente.

No último bloco da figura 5, estão resumidas algumas ações que vão contribuir e promover as condições para que torne-se possível o citado anteriormente. Sua concretização não é resultado de um ato singular (nem sequer de vários) no qual se concentrem saberes e intuições. Será um processo tenaz, contínuo, no qual os mecanismos empíricos de ensaio e erro são fundamentais para aproximar os projetos às expectativas e, também, no qual a potencialização de capacidades de direção e gerência públicas adquirem valor estratégico. São estratégicos, da mesma forma, a introdução de critérios de eficácia, eficiência e qualidade; as políticas de recursos humanos que sejam incentivadoras, atraentes, impulsionadoras do espírito de iniciativa e inovação; a atribuição de autonomia e responsabilidade aos gestores públicos; $\mathrm{e}$, finalmente, envolvendo a todos esses valores, um adequado recrutamento e promoção dos ativos de modo que a formação e preparação permanentes sejam os pilares sobre os quais repouse a nova cultura administrativa.

Às vezes, pretende-se insinuar, de maneira interessada, que com este processo se foge do marco e limites legais como uma tentativa - em casos desde a ignorância - de provocar inquietações na cidadania e de provocar o ressurgimento de reações contra o modelo. É preciso insistir na natureza contrária a essas opiniōes. São errôneas, pois, o respeito à legalidade não há de ser somente uma atitude passiva de cumprimento e escudo protetor, senão que deve entender-se como elemento impulsionador na execução das políticas para que cumpram com os fins e objetivos propostos na Constituição para o desenvolvimento equilibrado e justo. Os princípios de mudança mencionados não estão em conflito, senão que, como exposto em outras seções, são princípios legitimadores, complementares na ação administrativa.

\section{ALGUMAS DIFICULDADES E POSSÍVEIS AÇÕES}

É evidente que, ao nos aproximarmos dos constituintes elementares das políticas de recursos humanos, nos encontramos com os indivíduos que realizam sua vida, com suas esperanças e frustrações, na organização. No caso da Administração, sua importância é sem dúvida maior, pois, além de seu papel na produção, serão aqueles que aproximam o produto, quem o "vende", além de atender aos serviços "pós venda". E, caso se deseje acrescentar mais complicações, eles também são cidadãos e clientes; mais que isso - devem ser o sistema de comunicação pelo qual são canalizadas as aspirações e as respostas adequadas que pretende-se venham a ser adotadas pelos responsáveis políticos das decisões. Parece-me que é justo reconhecer o mérito que representa o fato de o coletivo de pessoal das Administrações Públicas ter adotado, como opção para a realização de sua vida, a de ajudar e procurar que o resto da sociedade tenha algumas garantias no desfrute e qualidade de sua vida.

Mas, feita esta declaração, temos que analisar algumas disfunções que são produzidas no funcionamento ordenado da Administração e que são achacadas como possíveis erros nas políticas de recursos humanos. Entre as mais perturbadoras, encontram-se as seguintes:

a. uma carência de acomodação entre a distribuição e a ordenação dos postos de trabalho e do pessoal e as necessidades e tarefas que devem ser desempenhadas pela organização;

b. uma falta e deterioração, mais visível em alguns setores que noutros, nos mecanismos de incentivo e motivação; c. a ausência de uma cultura gerencial na Administração, o que justifica, de certo modo, as dificuldades anteriores.

Quais são, então, algumas das possíveis ações que contribuiriam para desatar o nó górdio (ver figura 6). 
Para a acomodação dos Recursos Humanos às necessidades da Organização deveríamos atuar sobre:

1. a análise dos objetivos e finalidades, com o que seriam definidas as necessidades objetivas dos departamentos ou unidades da administração;

2. poderíamos adequar os R.P.T. (Relações de Postos de Trabalho) a estes objetivos ${ }^{7}$;

3. o estabelecimento de uma correlação entre necessidades reais e mecanismos de provisionamento;

4. em último lugar, deveria atribuir-se maior autonomia e responsabilidade aos órgãos dirigentes das unidades. ${ }^{8}$

Entre as ações que poderiam contribuir para a superação da débil iniciativa e as carências de motivação podem mencionar-se:

1. gerar condições que estimulem a inovação, a criatividade, a dedicação e assumpção de responsabilidades, em resumo naqueles quantos aspectos que incidem na satisfação pelo trabalho e atividade bem feitos;

2. estabelecer um sistema de carreiras coerente com os objetivos da organização que estivesse vinculada com a experiência e com a formação, de modo muito personalizado para que exista um certo grau de previsão para o futuro individual;

3. atuar sobre o sistema retributivo, adequando-o com os postos de trabalho e estimulando e valorizando o esforço, a dedicação, a responsabilidade e entrega do pessoal.

Para isso, é preciso que, $n$ Administração, as "carreiras" de seus empregados sejam formuladas e programadas, não tanto como reduto de garantia de direitos individuais e, sim, mais em acorde com as necessidades e orientações da organização.

8. Além disso, é preciso - e de acordo com o mencionado na nota 11 - que o principio de legalidade seja reformulado para que, nessas circunstâncias, não se contemple como espada de Damocles de forma a manter os dirigentes em tal grau de temor que thes dificulta a tomada de decisão e a responsabilidade conseqüente. blicos capazes de assumir a responsabilidade, de gerir o imprevisto e, acima de tudo, de dinamizar uma Administração que atenda com qualidade a seus usuários.

É evidente que, com estas medidas, pretendemos mudar as moribus antes que as lege, para que, em sendo possível, exista um ambiente social favorável à transformação da Administração em uma organização que atendesse com eficácia e qualidade ao conjunto de necessidades em que está assentado o Estado Social e de Direito. Não é um objetivo frívolo e contamos com que existam múltiplas dificuldades e resistências. Acreditamos que, a favor, joga a própria dinâmica da sociedade, que entende que os seus direitos e liberdades não estão garantidos apenas com o cumprimento minucioso e passivo da legalidade, senão que necessita de um comportamento mais ativo e diligente que permita perceber, de maneira efetiva, a concretização dos princípios de igualdade, justiça e não discriminação. Por isso que é uma exigência peremptória que a Administração acomode procedimentos, métodos e recursos humanos para que possa cumprir corretamente com estes objetivos.

A partir deste argumento não será estranho que abordemos, com alguma atenção suplementar, o tema do acesso e promoção do pessoal ao serviço das Administrações Públicas, por ser a etapa inicial, origem da expectativa futura que tem os recursos humanos. De início, teríamos que afirmar a inconveniência, para os fins que propomos, do atual método de seleção e, em grande parte, também dos mecanismos de promoção. Em nenhum dos dois casos se obedece a um projeto (diseño) global sobre quais sejam os objetivos que devem ser alcançados pela Organização e, menos ainda, sobre o papel que, nessa Organização, devam desempenhar os seus empregados. No máximo, são contempladas, sem ordem nem ajuste, conjecturas primárias de organização devidas a voluntarismo dos gestores e responsáveis, administrativos ou políticos, antes que uma decidida aposta para modificar tradicionais e obsoletos sistemas de recrutamento e promoção. Como configurar uma nova realidade? 


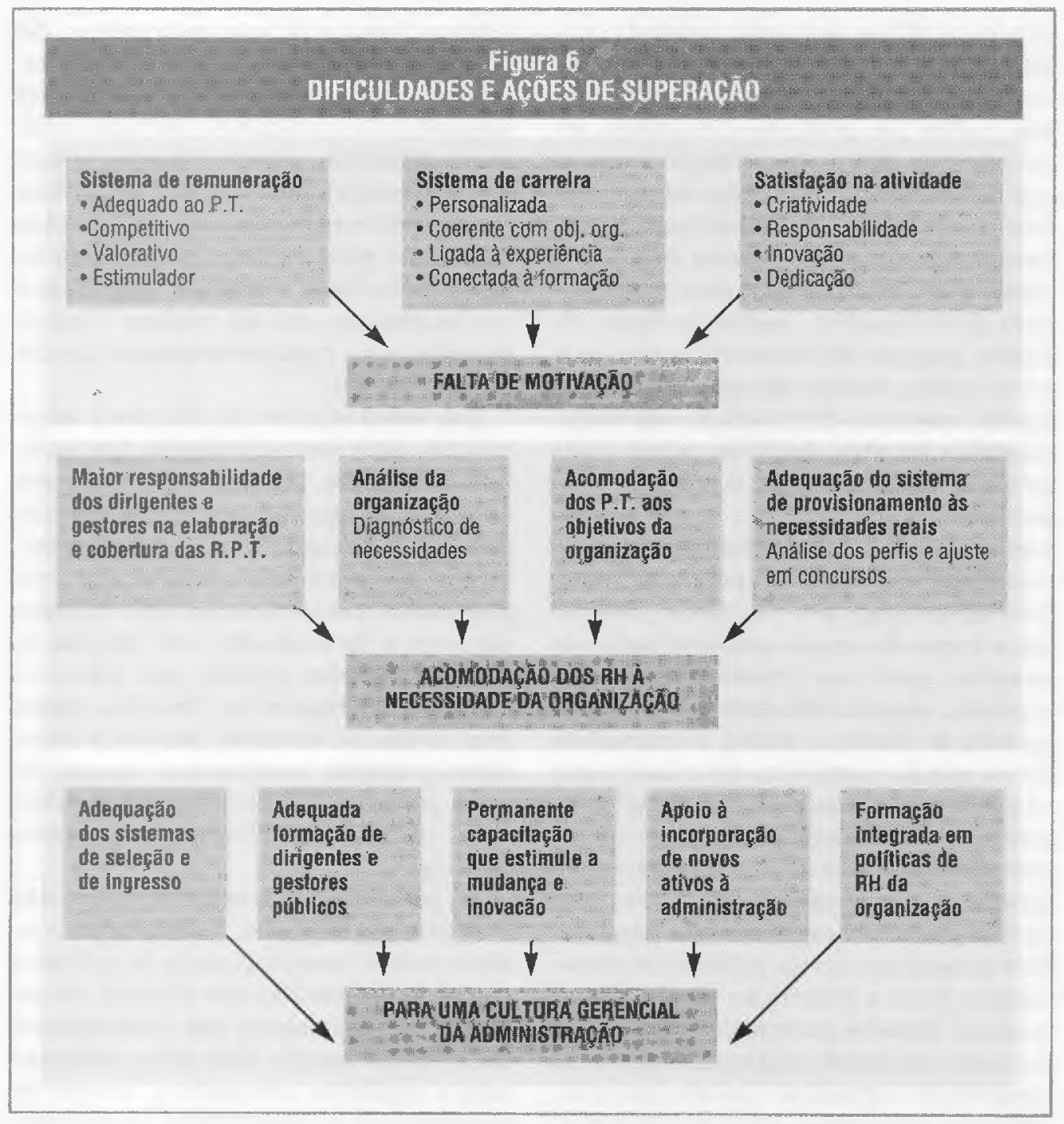

Iniciemos por aquilo que, provavelmente, possa provocar menores resistências. A aplicação das novas tecnologias nos escritórios (oficinas). $\mathrm{O}$ que tem sido chamado de "ofimática", pressupõe a mudança radical com respeito ao que era normal há apenas uma década. Sem haver chegado, ainda, ao "escritório sem papéis", produziu-se um avanço considerável. O parque informático multiplicouse consideravelmente, nos últimos anos, e o problema que se coloca é dar ocupa ção e rentabilidade a este esforço de investimento. Não é uma moda passageira, nem um adorno do escritório. São elementos de trabalho de alta capacidade e custo que podem incrementar a produção, ou que podem ser um novo desperdício a criticar. Os responsáveis pelas unidades devem ser os primeiros interessados em obter o máximo rendimento, porque thes evitará tarefas repetitivas e rotineiras, thes permitirá a administração em tempo real de múltiplos dados, relacionar e seguir os expedientes, estabelecer valorações e métodos de medida de seus objetivos e atividades, mas, acima de tudo, facilitará para que se possa oferecer ao cidadão uma atenção mais confiável, próxima e personalizada.

Naturalmente, isso implica uma nova cultura na qual a máquina, o processador ou o ordenador pessoal não seja visto como um inimigo ou rival desleal, senão como um colaborador que, trocando informação, ajude o funcionário a exercer as competências. É uma dimensão que deverá ser adquirida, também, pelos gestores e dirigentes públicos.

A partir desta perspectiva, que sentido tem seguir mantendo distinções na preparação e qualificação de ingresso, exigí- 
veis para ofícios que estão sofrendo modificações em razão da incorporação das novas tecnologias? Parece que não existem razões que avalizem a existência separada e de difícil comunicação entre os que se conhecem como corpo administrativo e auxiliares. Os conhecimentos determinantes de acesso estarão vinculados com o que devem ser as tarefas reais: manejo de ordenador, gestão de bases de dados, arquivo eletrônico etc. e não limitar-se a uma divisão (decimonica) entre as tarefas manuais de produção de documentos e escritos daquelas outras mais próprias da classificação e ordenação do escritório. A proposta que se possa apresentar deverá acolher esta orientação e consolidar um espaço de postos de trabalho diferenciados por sua função, dedicação a temas de atenção personalizada aos usuários, apoio nos trabalhos de direção e gestão, responsabilidade no manejo e guarda de bases de dados, documentais ou de gestão econômica, de maneira que se possa estabelecer pela organização, e a partir dos interesses pessoais, as condições de mobilidade que permitam a adequação das expectativas de carreira pessoal às previsões organizativas para melhor atender ao serviço público. Os mecanismos para a promoção deverão contemplar atitudes pessoais e experiência, levando em conta o aproveitamento na capacitação e aquisição das técnicas e habilidades requeridas pelos diversos postos de trabalho.

A aplicação de critérios gerenciais, concordes com os requisitos que são feitos à Administração, obriga a um reposicionamento (replanteamiento) sobre quais serão os perfis adequados que devem possuir aqueles que vão desempenhar as novas tarefas administrativas. Não podem ser adotados os mesmos métodos de seleção aplicados pela administração de normas e potentados, rígida e burocratizada, quando pretende-se obter respostas ágeis e eficazes às demandas de uma sociedade plural e dinâmica. Enquanto que na primeira hipótese, seria correto dispor de pessoas com pouca iniciativa - dóceis à influência da hierarquia e, por sua vez, frágeis transmissores da mesma - com escassa capacidade para assumir riscos e responsabilidade, embora isso sim, reconhece-se explicitamente, com amplos e numerosos saberes sobre a norma e de suas reviravoltas. No entanto, na hipótese de Administração para uma sociedade na incerteza, o que será requerido são qualidades e atitudes totalmente diferentes, como a intuição, o espírito de inovação, uma concreta capacidade de resposta frente a situações imprevistas, disposição para assumir responsabilidades e, além disso, a reflexão, prudência e conhecimentos que lhe ajudem a tomar decisões e na cuidadosa atenção às demandas sociais.

Este novo espectro de atitudes e capacidades deve ser reconhecido nos sistemas de seleção, acesso e promoção dos empregados que tenham responsabilidades de direção, gerência e gestão dos serviços e assuntos públicos. Daí que propugnemos transformações nos métodos seletivos e de avaliação e no sistema de carreira daquelas pessoas que, dados os postos a desempenhar, deverão contar com níveis de formação médios e superiores e estarão destinadas a cumprir tarefas próprias daquilo que em sentido geral poderíamos chamar de gerência pública.

Se, juntamente aos critérios de aptidão e de atitude, expostos, incluímos os condicionantes constitucionais de mérito e capacidade, acredito que poderia ser estabelecido um sistema que contemplasse duas vias de acesso, mais uma promoção com a regulação adequada e, na qual se considerasse a experiência, os conhecimentos e as habilidades que serão necessárias para os diversos postos de trabalho e que poderia adquirir-se através dos processos de formação externos e próprios da organização.

Deveríamos concretizar a atenção no nível superior da pirâmide de emprego $e$ enfatizar a necessidade de pessoal dirigente que suporte a máxima responsabilidade no bom funcionamento da organização para o cumprimento dos objetivos e finalidades que sejam encomendados e que, por sua vez, deve ser o elemento dinâmico de conexão e comunicação com o âmbito de análise e decisão políticas. Serão estes funcionários públicos aqueles que terão a seu encargo a modelagem das diversas políticas públicas em programas concretos de execução, respondendo com eficácia e qualidade aos requisitos da sociedade. Sendo assim, são também os 
mediadores entre os cidadãos-clientes que emitem suas manifestações de agrado ou insatisfação pelos serviços que recebe, e a organização - enquanto produtora desses bens cuja melhoria lhe compete, além de ser transmissores dos interesses plurais e da adequação das respostas aos órgãos públicos de decisão. Configura-se, então, um dirigente público com espírito de iniciativa, capaz de dinamizar e impulsionar sua organização, sensível às aspirações de seus clientes - reais ou potenciais, que possua habilidades para comunicação e negociação. Enfim, que possa projetar e programar suas atividades orientadas para o serviço público dentro de um marco de qualidade e responsabilidade.

Com estas tarefas e o perfil de qualidades que expusemos, o papel do funcionário dirigente não se afasta sensivelmente daquele desempenhado por um dirigente de qualquer corporação industrial, ou de serviços. Daí que, quanto a sistemas de seleção, promoção, compensação e retribuição, devemos também facilitar a aproximação e, inclusive, permeabilizar possíveis caminhos de mobilidade entre este tipo de responsáveis.

Realizamos esta análise com base numa matriz tradicional de empregos que está na figura 7. Não obstante, com ela não serão respondidas as múltiplas interrogações que dizem respeito a uma sociedade aberta, dinâmica e em incerteza. Teremos que avançar um pouco mais em uma provisão que nasce de situações que podem ser observadas desde já, principalmente naquelas atividades de maior aplicação da inovação tecnológica.

\section{QUAL PODE SER O FUTURO DE "CAPITAL" HUMANO?}

Até aqui procurei considerar quais poderiam ser os efeitos sobre uma estrutura piramidal tradicional de postos de trabalho, onde entende-se como normal uma ampla base de postos que não requerem uma excessiva preparação e uma cúpula dirigente que detém o máximo poder na hierarquia e para a qual supõe-se como necessária uma qualificação especial. Agora, do próprio texto pode deduzir-se, imediatamente, que nāo é suficiente com uma maquilagem - por ampla que seja - dos requisitos para ocupar os postos prefigurados nas relações de hierarquia que sustentam a pirâmide, senão que é preciso - diria até que já adquire um certo grau de peremptoriedade! - atuar sobre a própria estrutura, de maneira a que se acomode à nova realidade de postos de trabalho que vão surgindo; e, sobretudo, aos fenômenos de ruptura dos condicionantes imperativos horizontais e a geração de comunicações que favorecem o compartilhar no processo de tomada de decisão e execução.

Estimo que ambas as situações - incremento nas necessidades de qualificação (ou, caso se deseje, a redução evidente no número de empregos que exigem pouca preparação) e uma direção mais participada, com maior dispersão dos centros de responsabilidade e a presença de postos dirigentes que planejem mais, que sejam coordenados ou estimuladores das atividades - irão modificar a estrutura tradicional em uma tendência ao rebaixamento do vértice e redução da base como a figura de pirâmide deverá ser substituída por outra que suporte uma menor rigidez, maior flexibilidade e comunicação.

Na figura 8, mostra-se o que poderíamos pensar sobre qual será a evolução em futuro próximo, passando, possivelmente, por uma situação intermediária em que, contudo, serão mantidos certos graus de estrutura hierarquizada na qual deverão ser flexibilizados os procedimentos de comunicação vertical que facilitam a promoção e, coerente com o que se disse, serão reduzidos os postos associados aos princípios autoritários de hierarquia, rebaixando o vértice, e será reduzido drasticamente o volume de postos que requerem baixas qualificações. É difícil precisar a duração desta etapa intermediária, já que, somente a sua visão, pode provocar muitos mal-estares: incômodo, naqueles aspirantes com dificuldades de acesso a níveis mais elevados de formação básica ou que desejam uma colocação que não exija esforços pessoais excessivos; rejeição daqueles que entendem a sociedade e a Administração como um sistema autoritário e que sustentam seu posto na escala social através de manifestações impositivas de hierarquia; temores de que a maior mobilidade dê origem a atitudes de competição mais 


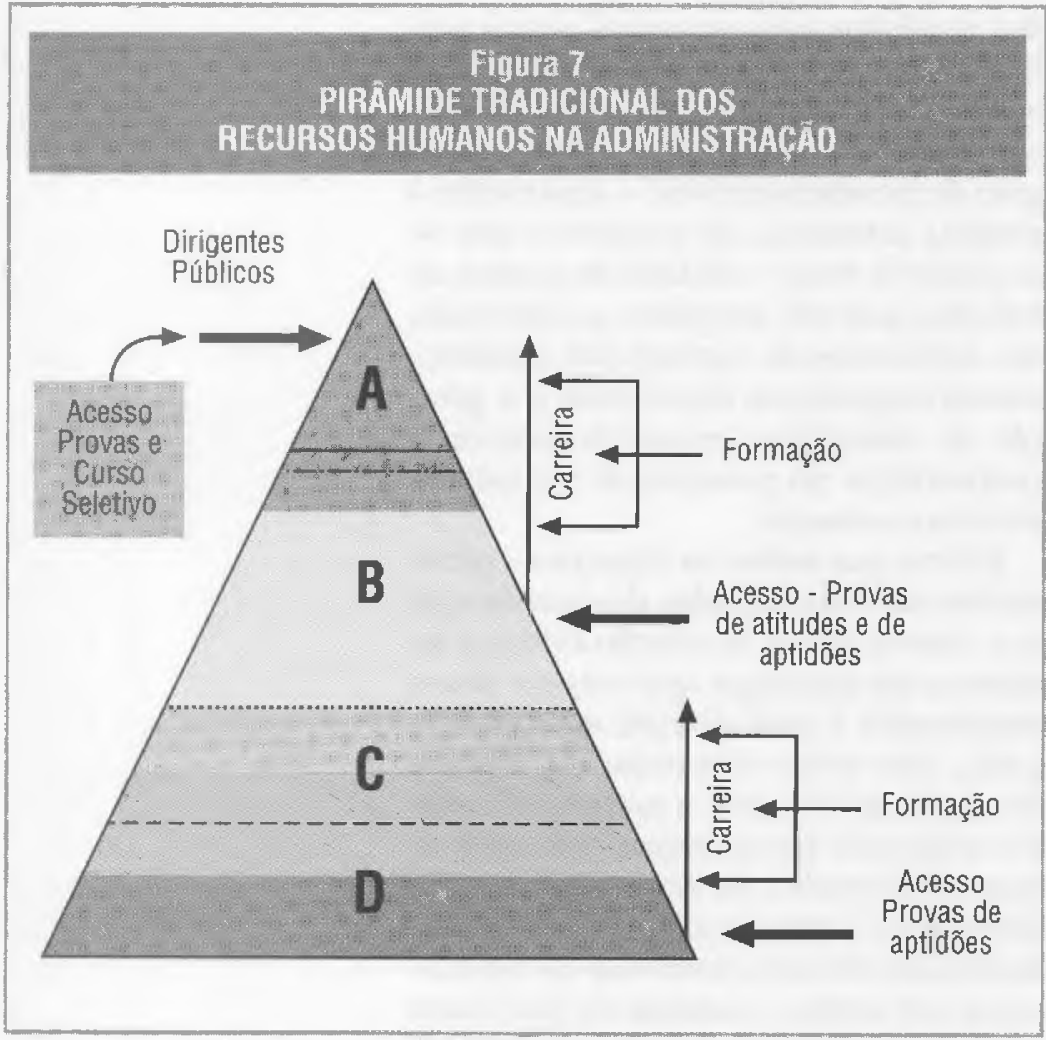

acentuada que perturbem situações estacionárias e inerciais, conseqüência de baixos níveis de atividade; finalmente, a maior distribuição da responsabilidade que deve estar associada às unidades de atuação, obrigará a um novo entendimento da direçâo, como elemento de animação, coordenação e planejamento das distintas políticas públicas, ao mesmo tempo que comunicador das aspirações e necessidades - ou dos resultados alcançados em sua aplicação, para que os encarregados da direção política possam proceder à contínua adequação de suas ofertas programáticas.

É evidente que este processo de transformação está iniciando sua caminhada. Pode comprovar-se em muitas corporações industriais ou de serviços, principalmente naquelas que necessitam ou já implantaram um maior suporte tecnológico. A Administração Pública também deve ajustar-se a esta tendência evolutiva e é por isso que, no caso espanhol, uma grande parte dos projetos considerados no Plano de Modernização, aprovado recentemente, conduzem à incorporação de novas tecnologias, a uma maior atenção na qualidade dos serviços, a produzir uma ampliação das unidades de respon- sabilidade e a gerar mecanismos de cooperação e coordenação que permitam prestar o serviço em proximidade com a demanda e, ao mesmo tempo, uma adequada comunicação, para evitar disfuncionalidades ou situações indesejáveis, de agravamento ou discriminação. Quanto tempo poderá agüentar, imperturbável, um esquema de relações trabalhistas, ou de funcionários, ancorado, com pequenas oscilações, no século passado? Minha impressão é que cada vez são menores as ligações; que aparecem rombos no casco envelhecido deste barco (barco varado en añoranzas); e que a própria pressão das demandas dos cidadãos - que se realimenta nas milhares de informações que recebe e com as quais pode comparar a sua realidade - terminará por romper um cascarrão, bastante ôco e em grande parte encobre procedimentos espúrios utilizados em proveito próprio por aqueles que constróem o seu ninho no velho e arrumado.

Por isso, é conveniente aprofundar a reflexão sobre o papel dos recursos humanos na organização administrativa, pelo menos a partir de duas perspectivas complementares:

a. quais são os perfis de atitudes e conhecimentos básicos que serão requeridos das pessoas que ascendem no serviço público. Esta questão afetará, sem dúvida, os projetos de currículos acadêmicos e, sobre os quais conviria iniciar, sem muita demora, análises e estudos comparativos com outros países - sobretudo com os mais próximos de nosso entorno europeu, que possam conduzir a um grau eficiente de acordo. Para abrir o debate, contemplo o administrador público do futuro como uma pessoa de ampla cultura, com atitudes de flexibilidade e adaptabilidade às mudanças e à inovação, sensível às demandas dos cidadãos, capaz de estabelecer meios de comunicação que facilitem o vazamento de informação bidirecional entre os cidadãos-usuários e os centros encarregados pela programação e planejamento das políticas públicas, que disponha de um espírito analítico que complemente o raciocínio lógico necessário para a modelização e conseqüente avaliação e, finalmente, 
esteja disposto a assumir a iniciativa $\mathrm{e}$ a responsabilidade nas decisões que lhe estão afetas. ${ }^{9}$ Se acrescentarmos a estas atitudes as habilidades e conhecimentos que devem lhes ser próprias para o exercício de sua função, estaremos preparando alguns recursos - capital - humanos que poderão gerenciar as tarefas de uma Administração para a incerteza que possa acomodar, a todo instante, os mecanismos de resposta à evolução das demandas dos cidadãos.

Acrescentaria a este perfil do empregado público do futuro, um aspecto que tem a ver com a situação aberta e de intercomunicação que consideramos como princípio básico e dinamizador. Não somente no caso dos países europeus - que devem estar aproximados a uma relação e interpenetração, mas também de uma perspectiva global, é necessária uma educação básica plurilingüística, que complete a identidade própria pertencente a uma determinada história cultural com a pertencência a um mundo inter-relacionado para o qual é requerido o conhecimento ativo, ou, no mínimo, passivo, de alguns dos idiomass mais utilizados na comunicação internacional;

b. o outro ângulo de observação seria desde a própria organização administrativa e consiste em saber como seria estabelecida a correlação entre as necessidades da organização - em função de suas competências e tarefas que deve cumprir - com a satisfação das aspirações, desejos de estímulo, compensação de esforços, motivação no trabalho etc. dos próprios empregados.

Nesta perspectiva, é preciso entender que, enquanto a estrutura piramidal é muito estratificada e com frágil intercâmbio entre os diversos núveis, as simetrias mais esferoidais resultam da mobilidade; podendo-se afirmar que o dinamismo é a característica mais evidente que pode ser observada neste tipo de estruturas. Freiálo significa que apareçam efeitos estratificantes que tendem ao repouso e, desde o ponto de vista sócio-trabalhista, a conformismos e inércias pouco estimulantes.

Portanto, a organização terá que prever as necessidades de postos requeridos

\section{Figura 8}

TENDENCIA EVOLUTIVA DA ESTRUTURA DE EMPREGOS
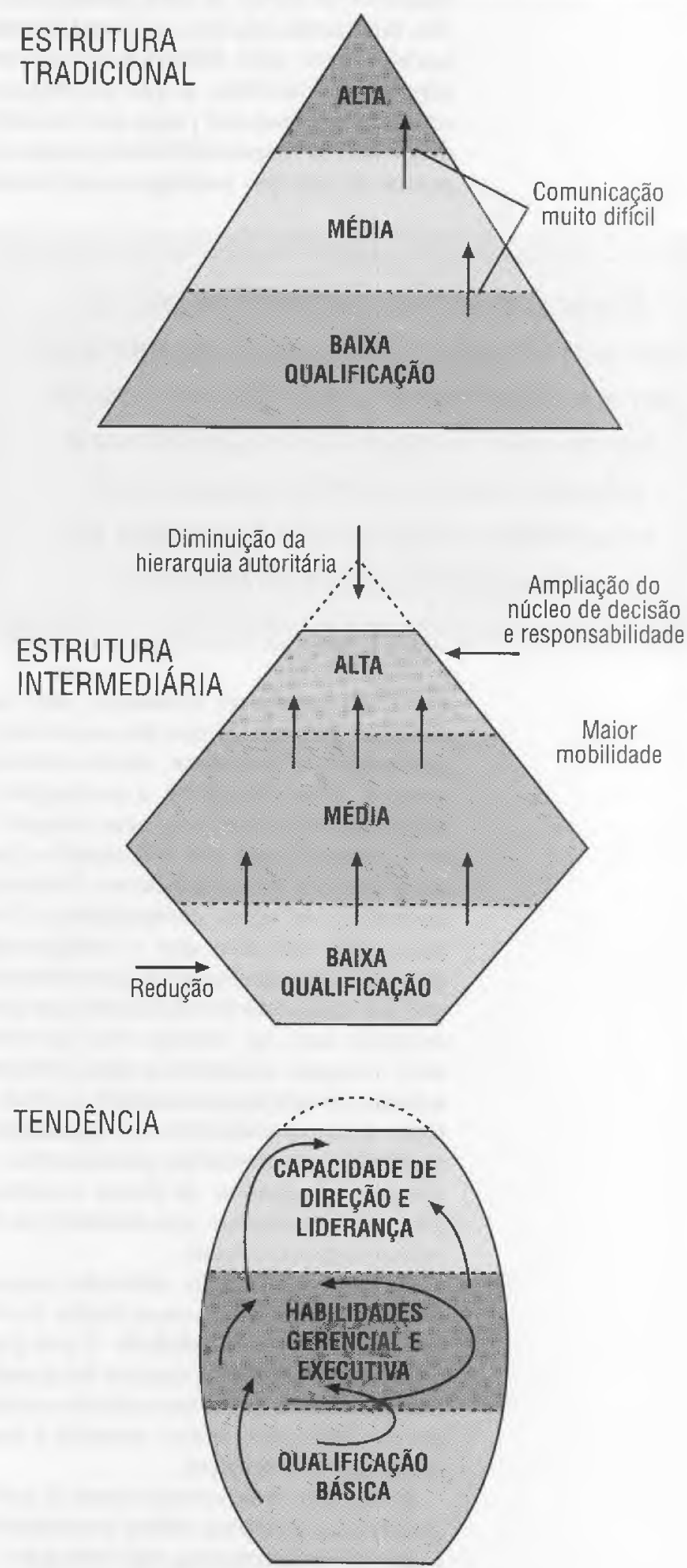
não de um modo estático, mas sim pensando que devem ser produzidas as dinâmicas que permitam aos empregados desenvolver todas as suas potencialidades, facilitando não só o que atenda satisfatoriamente uma determinada incumbência mas, também, o que ao longo de sua vida profissional possa ser incumbido de outras responsabilidades, tanto em postos de posição análoga ou em outras

\section{Novos projetos não poderiam manter-se} sem uma formação das pessoas responsáveis por seu desempenho. Disso derivou o amplo acordo sobre a importância que passam a adquirir, nas corporações empresariais, as unidades encarregadas das tarefas de adequação dos recursos humanos.

que the possam ser atribuídas, seja por estímulo próprio ou por interesses da organização. É evidente, muito embora sempre fosse desejável, a produção de deslocamentos positivos, nem sempre isto é possivel, seja por dificuldades pessoais como a de correlacionar interesses diversos e, às vezes, contraditórios. Com isso, quero ressaltar que a configuração de postos de trabalho da organização tem que ser adequada às finalidades que deve cumprir mas, no entanto, tem que possuir, a tempo, mecanismos que permitam a sua acomodação permanente e, além de tudo, camirhos através dos quais sejam realizados os itinerários pessoais dos diversos empregados, de modo a contemplar suas aspirações, sem distorcer os objetivos organizacionais.

Mudança, inovação, estímulo, responsabilidade, iniciativa, capacitação, devem estar na base da mobilidade. E esta pode introduzir energia no sistema de recursos humanos para que sejam obtidos melhores rendimentos, maior atenção e mais qualidade nos serviços.

Existe um observatório desde o qual é possivel contemplar ambas perspectivas e que até recentemente não tem sido devidamente cuidado e, às vezes, nem se- quer alcançado, pelas diversas organizações, tanto privadas como públicas. É o lugar que haverá de ser ocupado pelas unidades que se dedicam à seleção e formação dos empregados.

E possível que, antes da década de 70 , não houvesse a consciência da necessidade de dispor de pessoal capacitado e disposto a assumir novas tarefas. A estrutura rotineira do trabalho permitia a existência de uma multidão de postos que não requeriam maior aprendizagem que aquela associada com uma prática quase mecânica, sem contribuições intelectuais de nenhuma espécie, repetitiva e, em muitos casos, alienante. Não era preciso dispor de atitudes especiais, nem de prover-se de outras habilidades e conhecimentos que aqueles da disponibilidade obediente com um modelo estático, com comunicações débeis e no qual as relações de dependência eram estabelecidas por períodos indefinidos. $\mathrm{O}$ incremento de riqueza passava por investimentos materiais em instalações e utilidades.

Isso ocorreu até o momento em que a introdução de novas tecnologias - em particular as associadas com a informação e a informatização rompeu com os vínculos anteriores. $\mathrm{O}$ incremento de inversões em tecnologia nova conduziu ao contrário, em alguns casos, a situações de quebra, o que abriu os olhos de muitos responsáveis por empresas, iniciando-se um ciclo - em que nos encontramos atualmente, que obriga a considerar a preparação do capital humano como um elemento tão essencial, ou mais, que o capital financeiro ou material. Novos projetos não poderiam manter-se sem uma formação das pessoas responsáveis por seu desempenho. Disso derivou o amplo acordo sobre a importância que passam a adquirir, nas corporações empresariais, as unidades encarregadas das tarefas de adequação dos recursos humanos.

Se, a estas necessidades derivadas da incorporação tecnológica, acrescentarmos as condições da sociedade em rápida mudança e o fenômeno da comunicação, teremos que certificar-nos de nossa percepção sobre o papel que deve ser exercido pela formação, na urigem e no desenvolvimento dos itinerários dos trabalhadores - em particular dos empregados públicos, em suas organizações. $\square$ 